\title{
Interaction between dendritic radix structures of pelmatozoan echinoderms on a hardground in the middle Silurian (Wenlock) of southeastern Indiana, USA
}

\author{
James R. Thomka' $\cdot$ Carlton E. Brett ${ }^{2}$ \\ Received: 1 June 2019/Accepted: 29 July 2019/Published online: 9 August 2019 \\ (C) Akademie der Naturwissenschaften Schweiz (SCNAT) 2019
}

\begin{abstract}
A hardground surface in the middle Silurian (Wenlock: Sheinwoodian) Massie Formation is well exposed at the New Point stone quarry in Napoleon, southeastern Indiana, USA, where it is densely encrusted by pelmatozoan echinoderm attachment structures. Among the most common attachment structures encrusting the hardground are terminal dendritic radix structures attributable to the monobathrid camerate crinoid Eucalyptocrinites and the hemicosmitid rhombiferan Caryocrinites. Radicles belonging to both of these genera are often modified by secretion of secondary stereom, resulting in swollen, irregular calcitic masses that extend onto the substrate and can engulf nearby bioclasts. Herein, we describe a specimen that resembles a portion of a swollen radicular attachment structure; however, close inspection reveals that is actually an interaction between radicles of Caryocrinites and Eucalyptocrinites, as indicated by the presence of both a trilobate lumen, characteristic of Caryocrinites, as well as a pentalobate lumen, characteristic of Eucalyptocrinites. Hence, what appears to be part of a single structure is actually parts of two interwoven structures belonging to entirely different taxa. Increased attention to echinoderm attachment structures consisting of overgrowths and secondarily mineralized radicles may result in recognition of additional specimens that represent analogous biotic interactions rather than simple holdfast occurrences.
\end{abstract}

Keywords Caryocrinites $\cdot$ Eucalyptocrinites $\cdot$ Sheinwoodian $\cdot$ Massie Formation · Holdfasts

\section{Introduction}

Marine hardground surfaces formed by early cementation of the seafloor, often associated with periods of rapid sealevel rise and resultant stabilization of redox boundaries (McLaughlin et al. 2008), present excellent opportunities to study palaeoecological phenomena, as encrusting organisms are indisputably preserved in situ. Spatial distributions, clustering patterns, overgrowth relationships, and evidence for competition for space can all be directly observed if sufficient bedding plane exposures are

Editorial Handling: D. Marty.

James R. Thomka

jthom059@plattsburgh.edu

1 Center for Earth and Environmental Science, State University of New York at Plattsburgh, Plattsburgh, NY 12901, USA

2 Department of Geology, University of Cincinnati, Cincinnati, OH 45221, USA available for study (Taylor and Wilson 2003). Among pelmatozoan echinoderms, attachment structures cemented to hardgrounds are among the most taphonomically robust of skeletal modules (e.g., Lewis 1982; Brett et al. 1997, 2008; Thomka and Brett 2014b), permitting documentation and interpretation of palaeoecologically informative assemblages or specimens even in settings otherwise characterized by poor fossil preservation.

The present study is a description of a specimen that initially appears to represent a portion of a single pelmatozoan attachment structure encrusting a middle Silurian hardground; however, careful inspection reveals that this seemingly simple fossil actually consists of two interacting attachment structures attributable to distantly related echinoderm taxa. This find is noteworthy as a contribution to the understanding of palaeoecological dynamics in hard substrate-encrusting communities as well as the palaeosynecology of Palaeozoic stalked echinoderms. Furthermore, specimens such as the one described herein provide the impetus for investigation of material that might 
otherwise be overlooked as typical and/or uninteresting parts of attachment structures seemingly incapable of yielding palaeosynecological information rather than as evidence for biotic interaction.

\section{Locality, horizon, and material}

The specimen described herein was recovered from a wellexposed, laterally continuous hardground surface at the northern end of the New Point Stone quarry in Napoleon, Ripley County, southeastern Indiana, USA (N39 $12^{\prime} 31.39^{\prime \prime}$, W85 $18^{\circ} 53.74^{\prime \prime}$; Fig. 1). This surface represents the contact between the basal carbonate lithofacies and the overlying mudstone lithofacies of the middle Silurian (Wenlock: Sheinwoodian) Massie Formation (Brett et al. 2012), a contact that previous workers (e.g., Foerste 1897; Frest et al. 2011) had recognized as the boundary between the 'middle Osgood limestone' and the 'upper Osgood shale' prior to regional lithostratigraphic revisions. Hardground formation reflects sediment starvation associated with the most rapid rate of relative base-level rise during a third-order stratigraphic sequence (McLaughlin et al. 2008; Brett et al. 2012; Thomka and Brett 2015a).

This hardground has been the subject of several recent studies focusing on the abundant and diverse assemblage of encrusting attachment structures belonging to pelmatozoan echinoderms (Thomka and Brett 2014a, b, 2015a, b, 2017; Thomka and Motz 2014). To date, 13 holdfast morphologies have been identified, including those attributable to holocystitid and sphaeronitid diploporitans, hemicosmitid rhombiferans, and camerate (as well as potential flexible, cladid, and disparid) crinoids (Thomka and Brett 2015a, 2017). Some of the most common attachment structures encrusting the Napoleon quarry hardground are dendritic radix structures belonging to the monobathrid camerate crinoid Eucalyptocrinites and the hemicosmitid rhombiferan Caryocrinites (Thomka and Brett 2015a, b).

Although the attachment structures of these two taxa are morphologically similar, they can be distinguished from one another on the basis of lumen size and shape, and

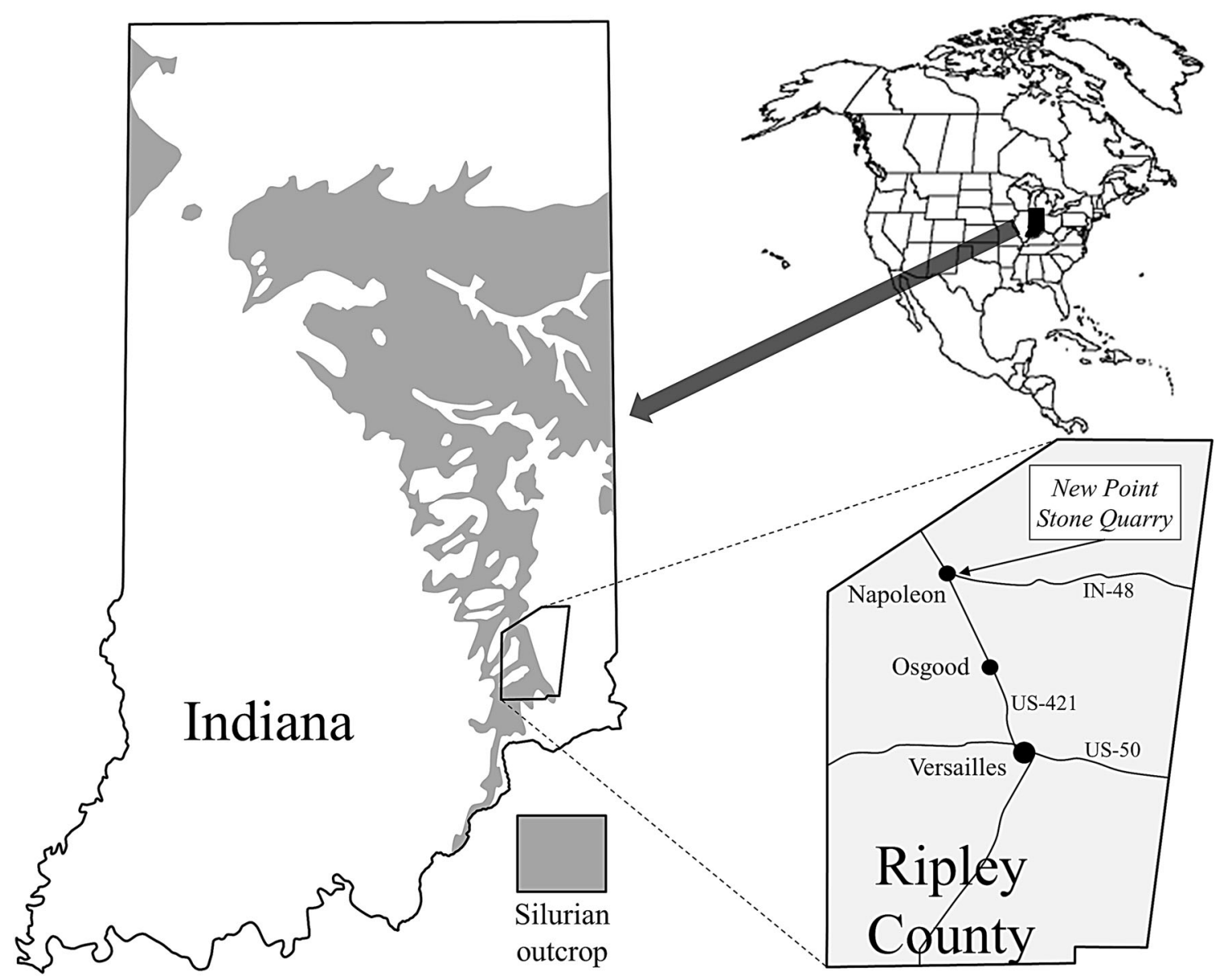

Fig. 1 Location of the study area, the New Point Stone quarry east of Napoleon, Ripley County, Southeastern Indiana, USA. The specimen was collected from a laterally continuous hardground in the northern part of the quarry. Figure from Thomka and Brett (2015a, fig. 1) 
radicular structure. Lumina are trilobate and comparatively large in Caryocrinites, and pentalobate and comparatively small in Eucalyptocrinites (Halleck 1973; Brett 1981; Thomka and Brett 2015a). Radicles consist of solid rods of undifferentiated stereom with no lumina in Caryocrinites, in contrast to the recognizable lumen-bearing ossicles, often coated in a cortex of secondary stereom, in Eucalyptocrinites (Brett 1978, 1981, 1984; Thomka and Brett 2015a, b; Plotnick et al. 2016).

\section{Description of specimen}

The material described herein is reposited in the Cincinnati Museum Center (Cincinnati, Ohio, USA), under specimen number CMC IP82656 (Fig. 2). It consists of a whitecoloured mass of echinodermal skeletal calcite embedded in a light-brown biomicrite matrix. Echinoderm material is oriented parallel to the bedding plane and is strongly cemented to the surrounding sedimentary rock, indicating encrustation of a hardground surface. The upper surface has the appearance of a wide, irregularly rod-like mass-a radicle-with numerous thin, thread-like extensions of calcite extending from both sides of the radicle into immediately adjacent sedimentary rock (Fig. 2A). This structure seemingly represents a portion of one primary branch of a distal radicular attachment structure, with the smaller tendril-like extensions serving to increase surface area of encrustation (Brett 1981, 1984; Thomka and Brett 2015a). The radicle is knobby and uneven in thickness throughout the visible surface, suggesting development of a coating of secondary stereom, as is commonly observed in attachment structures in both softground and hardground settings (e.g., Brett 1978, 1981, 1984; Thomka and Brett 2015a).

When viewed in cross-section (Fig. 2b), it becomes apparent that the specimen does not represent a single radicle, but, instead and exceptionally, represents two radicles that were interwoven into one composite structure. This is indicated by the presence of two discrete lumen structures, one with a trilobate lumen (representing Caryocrinites) and the other with a pentalobate lumen (representing Eucalyptocrinites). Both radicles have relatively large diameters, reflecting the overgrowth by secondary stereom (Fig. 2b). The Caryocrinites radicle is uniformly circular in outline, in contrast to the somewhat crescentshaped outline of the Eucalyptocrinites radicle (Fig. 2b); the more irregular shape of the Eucalyptocrinites radicle appears to reflect overgrowth of the Caryocrinites radicle.

Investigation of the smaller branches extending off of the main radicles confirms the identity of this specimen as a composite Caryocrinites-Eucalyptocrinites structure. The branches emanating from the pentalobate lumen-bearing radicle contain minute pentalobate lumina of their own
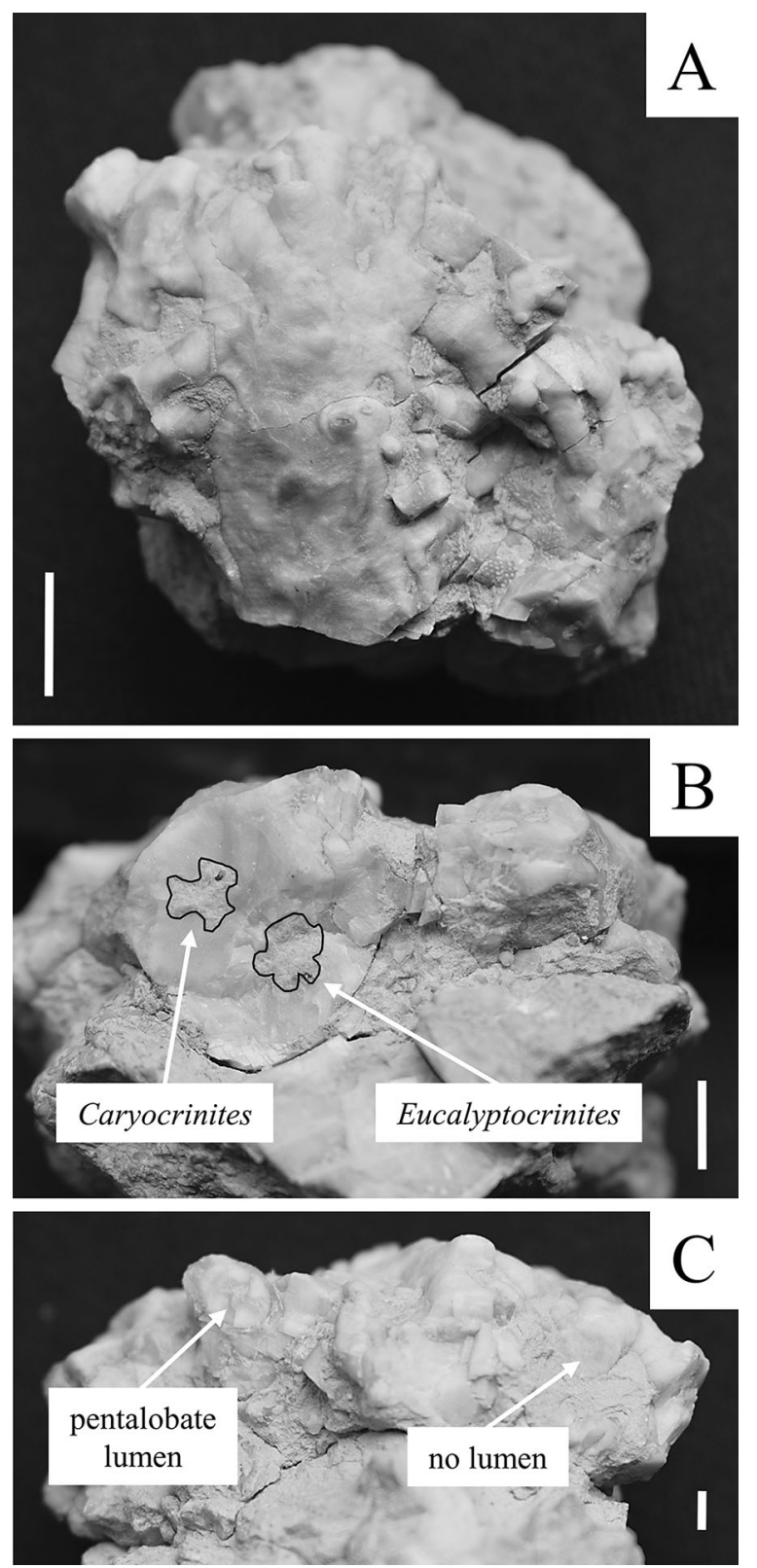

Fig. 2 Portions of the dendritic radix structures of the hemicosmitid rhombiferan Caryocrinites and the monobathrid camerate crinoid Eucalyptocrinites from the middle Silurian Massie Formation of the Napoleon quarry (CMC IP82656). Radicles from these two pelmatozoans became interwoven into one composite structure. a. View of the upper surface of the specimen, which has the appearance of a single radicle that is swollen with secondary stereom. Scale bar $=10 \mathrm{~mm}$. b. Cross-sectional (articular) view of the radicles, with the trilobate lumen of Caryocrinites and the pentalobate lumen of Eucalyptocrinites outlined. The uppermost lobe of the pentalobate lumen appears enlarged due to the angle at which this portion of the specimen is fractured. Note also that the Caryocrinites radicle has a circular outline, in contrast to the more irregular outline of the Eucalyptocrinites radicle. Scale bar $=5 \mathrm{~mm}$. c. Close-up view of some of the branches off of the main axis of the radicles. Those belonging to Eucalyptocrinites are characterized by minute pentalobate lumina, whereas those belonging to Caryocrinites are solid, undifferentiated rods of stereom lacking lumina. Scale bar $=2 \mathrm{~mm}$ 
(Fig. 2c), as has been documented for Eucalyptocrinites in other studies (Brett 1981, 1984; Thomka and Brett 2015a; Plotnick et al. 2016). The branches extending from the trilobate lumen-bearing radicle contain no lumina and do not appear to be divisible into distinct component ossicles (Fig. 2c), as is consistent with the radix structure of Caryocrinites (Brett 1978, 1981; Thomka and Brett 2015a). The boundary between these two radicles is not visible on the upper surface of the specimen, testifying to the degree of interpenetration between the stereomic overgrowths produced by these echinoderms.

\section{Discussion}

A number of palaeoautecological relationships have been described from the Napoleon quarry hardground, including those between attachment structure morphology and substrate consistency (Thomka and Brett 2015a), and amorphous stereomic overgrowths on holdfasts encrusting fistuliporoid-micrite microbioherms (Thomka and Brett 2015b). Fewer palaeosynecological relationships have been documented, with exceptions including parasitic embedment structures in diploporitan and crinoid thecae, and changes in the outline of discoidal diploporitan holdfasts resulting from competition for space (Thomka and Brett 2014b). This study contributes further information on the nature of interspecific interactions between hard substrateencrusting echinoderms on a densely encrusted surface occupied by a diverse pelmatozoan community.

The fact that the radicles of both echinoderms are expanded and irregularly swollen by secondary stereom indicates that both had to have been alive at the time of interaction and that both were actively engaged in attempts to overgrow the other attachment structure. This evidence of behaviour is discernable from simple encrustation of bioclasts in the sedimentary rock proximate to radicles (e.g., Brett 1978). Competition for space is a possible interpretation of this interaction, as well-developed dendritic radix structures attributable to both Caryocrinites and Eucalyptocrinites (as opposed to attachment structures that are more crustose and bear poorly developed radicles) are only found in poorly sorted, presumably partially sedimentfilled, troughs on the topographically undulating Napoleon hardground (Thomka and Brett 2015a). If attachment structures were not directly cemented to the hardground surface itself, increased surface area would be highly beneficial for increasing stability in the rubbly, unstable material partially infilling hardground troughs (Thomka and Brett 2015a). This substrate specificity results in space becoming a limiting factor for these relatively large, laterally sprawling attachment structures (see Brett 1991), and, therefore, might result in competitive interactions even on hardgrounds that are not so densely encrusted that intense competition would be expected.

In general, pelmatozoan attachment structures represent the most under-studied portion of echinoderm skeletons (e.g., Lewis 1982; Donovan et al. 2007; Thomka and Brett 2014a, 2015a). Although this is somewhat understandable given the need for crown or thecal material to identify pelmatozoans to low taxonomic levels, holdfasts and dististelar structures remain under-utilized in palaeoecological studies. The specimen described herein provides further evidence that consideration of attachment structures can yield valuable and interesting palaeoecological data without requiring exceptional preservation. Rather, the most informative aspect of the present study stems from the fact that this material would likely be completely overlooked as a simple radicle in nearly all studies when it is, in fact, more complex and consists of multiple interacting radicles-belonging to taxa within two different subphyla, no less. Even seemingly simple fossils should not be immediately interpreted as such, especially when the highly dynamic endoskeletons of echinoderms are involved.

Acknowledgements The owners and managements of the New Point Stone quarry at Napoleon, Indiana are thanked for allowing access to the study site. Funding for this study was provided by a Dry Dredgers Paleontological Research Award and a Paleontological Society N. Gary Lane Research Grant to JRT. Assistance in the field was provided by Thomas E. Bantel and Donald L. Bissett of the Dry Dredgers. Curation of the studied specimen was facilitated by Brenda R. Hunda (Cincinnati Museum Center). Previous versions of this article were improved by the constructive reviews by Stephen K. Donovan (NCB-Naturalis) and an anonymous reviewer.

\section{References}

Brett, C. E. (1978). Attachment structures in the rhombiferan cystoid Caryocrinites and their paleobiological implications. Journal of Paleontology, 52, 717-726.

Brett, C. E. (1981). Terminology and functional morphology of attachment structures in pelmatozoan echinoderms. Lethaia, 14, 343-370.

Brett, C. E. (1984). Autecology of Silurian pelmatozoan echinoderms. In M. G. Bassett \& J. D. Lawson (Eds.), Autecology of Silurian organisms (pp. 87-120). London: Palaeontological Association. (Special Papers in Palaeontology 32).

Brett, C. E. (1991). Organism-sediment relationships in Silurian marine environments. In M. G. Bassett, E. D. Lane, \& D. Edwards (Eds.), The Murchison Symposium: Proceedings of an International Symposium on the Silurian System (pp. 301-344). London: Palaeontological Association. (Special Papers in Palaeontology 44).

Brett, C. E., Cramer, B. D., McLaughlin, P. I., Kleffner, M. A., Showers, W. J., \& Thomka, J. R. (2012). Revised TelychianSheinwoodian (Silurian) stratigraphy of the Laurentian midcontinent: Building uniform nomenclature along the Cincinnati Arch. Bulletin of Geosciences, 87, 733-753.

Brett, C. E., Deline, B. L., \& McLaughlin, P. I. (2008). Attachment, facies distribution, and life history strategies in crinoids from the Upper Ordovician of Kentucky. In W. I. Ausich \& G. D. Webster 
(Eds.), Echinoderm Paleobiology (pp. 22-52). Bloomington: Indiana University Press.

Brett, C. E., Moffat, H. A., \& Taylor, W. L. (1997). Echinoderm taphonomy, taphofacies, and Lagerstätten. In J. A. Waters, \& C. G. Maples (Eds.), Geobiology of Echinoderms (pp. 147-190). Columbus: Paleontological Society, Paleontological Society Papers 3.

Donovan, S. K., Harper, D. A. T., \& Håkansson, E. (2007). The root of the problem: Palaeoecology of distinctive crinoid attachment structures from the Silurian (Wenlock) of Gotland. Lethaia, 40, 313-320.

Foerste, A. F. (1897). A report on the middle and upper Silurian rocks of Clark, Jefferson, Ripley, Jennings, and southern Decatur Counties, Indiana. Indiana Department of Geology and Natural Resources Annual Report, 21, 213-288.

Frest, T. J., Strimple, H. L., \& Paul, C. R. C. (2011). The North American Holoycystites fauna (Echinodermata, Blastozoa: Diploporita): Paleobiology and systematics. Bulletins of American Paleontology, 380, 1-141.

Halleck, M. S. (1973). Crinoids, hardgrounds, and community succession: The Silurian Laurel-Waldron contact in southern Indiana. Lethaia, 6, 239-252.

Lewis, R. D. (1982). Holdfasts. In J. Sprinkle (Ed.), Echinoderm Faunas from the Bromide formation (Middle Ordovician) of Oklahoma (pp. 57-64). Kansas: University of Kansas Paleontological Contributions Monograph.

McLaughlin, P. I., Brett, C. E., \& Wilson, M. A. (2008). Hierarchy of discontinuity surfaces and condensed beds from the middle Paleozoic of eastern North America: Implications for cratonic sequence stratigraphy. In B. Pratt \& C. Holmden (Eds.), Dynamics of Epeiric seas (pp. 175-200). Canada: Geological
Association of Canada. (Geological Association of Canada Special Paper 48).

Plotnick, R. E., Ebey, C. M., \& Zinga, A. (2016). A radicle solution: Morphology and biomechanics of the Eucalyptocrinites 'root' system. Lethaia, 49, 130-144.

Taylor, P. D., \& Wilson, M. A. (2003). Palaeoecology and evolution of marine hard substrate communities. Earth Science Reviews, $62,1-103$.

Thomka, J. R., \& Brett, C. E. (2014a). Diploporite (Echinodermata, Blastozoa) thecal attachment structures from the Silurian of southeastern Indiana. Journal of Paleontology, 88, 179-186.

Thomka, J. R., \& Brett, C. E. (2014b). Taphonomy of diploporite (Echinodermata) holdfasts from a Silurian hardground in southeastern Indiana, United States: Palaeoecologic and stratigraphic significance. Geological Magazine, 151, 649-665.

Thomka, J. R., \& Brett, C. E. (2015a). Paleoecology of pelmatozoan attachment structures from a hardground surface in the middle Silurian Massie Formation, southeastern Indiana. Palaeogeography Palaeoclimatology Palaeoecology, 420, 1-12.

Thomka, J. R., \& Brett, C. E. (2015b). Palaeontological and sedimentological effects of micro-bioherms in the Middle Silurian Massie Formation of southeastern Indiana, USA. Lethaia, 48, 172-187.

Thomka, J. R., \& Brett, C. E. (2017). The holdfast of Finitiporus boardmani (Echinodermata: Diploporita) in the Silurian Massie Formation of the Cincinnati Arch region, USA. Swiss Journal of Palaeontology, 136, 365-368.

Thomka, J. R., \& Motz, G. J. (2014). First report of Silurian crinoid columnals with tetralobate and hexalobate lumen structures. GFF, 136, 266-269. 